\title{
HOW TO SPEND MONEY?
}

\author{
The following are extracts from the Presidential Address to the Institute of Physics \\ and the Physical Society, entitled "Rate of Growth of Expenditure on Science", \\ delivered on May 3, 1966, by Sir Gordon Sutherland, Master of Emmanuel College, \\ Cambridge.
}

THE expenditure of the research councils has grown over the past 25 years as shown by the figures in Table 1 (taken largely from the report of the Advisory Council for Scientific Policy for 1963/64). In 1938/39 the total expenditure of the research councils was $£ 1.43$ million. By $1964 / 65$ this had grown to nearly $£ 50$ million. The overall compound annual per cent increase is $14 \cdot 6$ over the 26 years. It is on the basis of these figures that the statement is often made that Britain has been doubling her expenditure on science every 5 years.

The expenditure of the universities on research in science and technology shows a similar trend, although the period for which reasonably accurate figures are available is much shorter. The figures are given in Table 2. Here we find that expenditure has risen from $£ 20$ million in $1958 / 59$ to more than $£ 50$ million in $1964 / 65$. If we divide this interval into two periods of 3 years, then the compound annual per cent increase increased from 13.3 for the first three years to $19 \cdot 1$ for the last three. Thus in the research councils and the universities the annual expenditure is not only rising but the rate at which it is rising is also increasing. It is this increase in the rate of increase which is rightly beginning to cause concern. If these trends were to continue for even 10 years, the expenditure of the research councils would by 1974/75 have reached a total of about $£ 240$ million, which is considerably more than all government departments were spending on civil research ( $£ 204$ million) in $1964 / 65$. A similar extrapolation of the university figures leads to a total for the universities from the University Grants Committee alone of about $£ 235$ million. Thus the combined total for research carried out at universities and by the research councils would be about $£ 475$ million in $1974 / 75$ - a total which is nearly equal to the estimated combined expenditure on road construction ( $£ 192$ million) and the whole of the Ministry of Aviation (£299 million) for the year $1965 / 66$.

\begin{tabular}{|c|c|c|c|c|c|c|c|c|}
\hline ble & $1938 / 9$ & & $1947 / 8$ & & $1955 / 6$ & 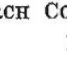 & $1962 / 3$ & $1964 /$ \\
\hline \multirow[t]{2}{*}{$\begin{array}{l}\text { D.S.I.R. } \\
\text { A.R.C. } \\
\text { M.R.C. } \\
\text { N.C. }\end{array}$} & $\begin{array}{l}0.89 \\
0.32 \\
0.22 \\
-\end{array}$ & & $\begin{array}{l}3 \cdot 08 \\
0 \cdot 97 \\
0 \cdot 77 \\
-\end{array}$ & & $\begin{array}{l}6 \cdot 48 \\
4 \cdot 0 \\
2 \cdot 2 \\
0 \cdot 21\end{array}$ & & $\begin{array}{r}21.87 \\
7.71 \\
5.86 \\
0.66\end{array}$ & \\
\hline & $1 \cdot 43$ & & 4.82 & & 12.89 & & $36 \cdot 10$ & $49 \cdot 4$ \\
\hline $\begin{array}{l}\text { ompou } \\
\text { perce }\end{array}$ & $\begin{array}{l}\text { annual } \\
\text { acrease }\end{array}$ & $14 \cdot 4$ & & $13 \cdot 0$ & & $15 \cdot 8$ & & $16 \cdot 6$ \\
\hline
\end{tabular}

It is conceded by all scientists that the exponential growth of expenditure on scionce cannot continue indefinitely at a figure (15-20 per cent per annum) which is so out of line with the exponential rate of growth of the G.N.P. of the country as a whole (about 6 per cent per annum at current prices between 1956 and 1965). How can we decide $(a)$ when to start cutting back the rate of increase, $(b)$ how much and at what rate to cut back, and $(c)$ the correct annual rate of increase at which we should finally stabilize?

One obvious line of attack is to examine the figures available for expenditure on all research in various countries and to relate them to the gross national product. For Britain, the relevant figures available are given in Table 3. It will be seen that in $1955 / 56$ the total expenditure by government and industry, private and nationalized, was only 1.64 per cent of the G.N.P. By 1961/62, this had risen to 2.5 per cent, and the best current estimate for $1964 / 65$ leads to much the same figure $(2 \cdot 44$ per cent). Over the past three years of this period, total expenditure on research by the four councils and the universities rose from 0.21 per cent of the G.N.P. to 0.28 per cent. Over the same period, expenditure by all industry showed a much smaller rise, that is, from 0.98 per cent of the G.N.P. to 1.04 per cent. Thus the compound annual rate of increase of expenditure by the research councils and the universities (10.1 per cent) was more than five times that of all industry $(2 \cdot 0$ per cent) when expressed as a percentage of the G.N.P. Extrapolating these figures, we find that in $1974 / 75$ the research councils and universities would be spending 0.75 per cent of the G.N.P., while the whole of industry would be spending $1 \cdot 3$ per cent. Are such figures reasonable?

We have seen that Britain's total expenditure on research and development seems to have stabilized at around 2.5 per cent of the G.N.P. However, if the rates we have been discussing were maintained, then by 1974/75 all industry together with the research councils and universities would be spending 2.05 per cent of the G.N.P. If we merely maintain all the other expenditure on research as a constant factor of the G.N.P. (1.04 per cent), then the grand total of expenditure on research and development by $1974 / 75$ would be $3 \cdot 1$ per cent of the G.N.P. According to a recent O.E.C.D. investigation, the percentages of the G.N.P. spent on research in 1962 by a number of highly industrialized countries were as follows:

United States
United Kingdom
Netherlands
France
Germany
Belgium

In view of the fact that France and Germany each have achieved an economic situation which is much stronger than the British, it would seem difficult to justify Britain going up to the United States figure of 3 per cent of the G.N.P. in the next ten years, and surely it would be wrong to spend one quarter of that money on basic research. Some decrease in the rate of growth of expenditure by the research councils and the universities on research seems inevitable in the near future.

The techniques used in pure scientific research are becoming more and more expensive as new discoveries in one field become applicable to an entirely different branch of science; for example, nuclear magnetic resonance and the Mössbauer effect, discovered by physicists, are now widely used in chemical research; electron microscopes and computers are gradually being used in nearly every branch of science. This is often referred to nowadays as "the sophistication factor", that is to say, the additional cost required in order to keep a research laboratory up to date technologically.

We might take the figures for a recent three-year period at the National Physical Laboratory to illustrate these trends in salaries and equipment costs. The N.P.L. is sufficiently large and varied to be representative of a cross-section of research laboratories in non-nuclear physics, metallurgy, aerodynamies and ship hydro-

Table 2. EXPENDITURE ON RESEARCH BY UNIVERSITTES (

\begin{tabular}{|c|c|c|c|c|c|c|c|}
\hline & $1958 / 9$ & $1959 / 80$ & $1960 / 1$ & $1901 / 2$ & $1962 / 3$ & $1963 / 4$ & $1964 / 5$ \\
\hline \multirow[t]{2}{*}{$\begin{array}{l}\text { U.G.c.c. } \\
\text { R.C. }\end{array}$} & $\begin{array}{r}16 \cdot 4 \\
3 \cdot 6\end{array}$ & $\begin{array}{r}18 \cdot 2 \\
4 \cdot 6\end{array}$ & $\begin{array}{r}19 \cdot 0 \\
6 \cdot 1\end{array}$ & $\begin{array}{r}21.2 \\
7.9\end{array}$ & $\begin{array}{l}26 \cdot 4 \\
10 \cdot 1\end{array}$ & $\begin{array}{l}31 \cdot 0 \\
12 \cdot 1^{*}\end{array}$ & $\begin{array}{l}37.1 \\
14.8 \dagger\end{array}$ \\
\hline & 20.0 & 22.8 & $25 \cdot 1$ & $29 \cdot 1$ & 36.5 & $43 \cdot 1$ & $51 \cdot 8$ \\
\hline entag & f comp & & & & & & \\
\hline
\end{tabular}

growth rate

* Provisional.

$\uparrow$ Estimated. 
Table 3. Expenditure on Crvil Research relaten to U.K. Gross National Product

G.N.P. at current prices in $£ 000$ million Total $R$ and $D$ in $£$ million

(\% of G.N.P.)

年

(\% of G.N.P.)

C. and university expenditure in $£$ million

( $\%$ of G.N.P.)

ate industry and public corporations in $£$ million

Universities alone in $£$ million

(\% of G.N.P.)

* Preliminary figure.

$1955 / 6$
$18 \cdot 32$
300
$(1 \cdot 64)$
$?$
$?$
$77 \cdot 3$
$(0 \cdot 42)$

$1959 / 60$

$1960 / 1$

$1961 / 2$

$1962 / 3$

$22 \cdot 7$

$24 \cdot 3$

$634 \cdot 3$

634
$(2 \cdot 5)$
137

$(0 \cdot 54)$

$52 \cdot 8$
$(0 \cdot 21)$

$247 \cdot 7$

$(0 \cdot 98)$

$22 \cdot 8$

$\frac{25 \cdot 1}{(0 \cdot 1)}$

$29 \cdot 1$
$(0 \cdot 12)$
154
$(0.57)$
62.5
$(0.23)$


36.5
$(0.135)$

$\begin{array}{cc}1963 / 4 & 1964 / 5 \\ 28 \cdot 9 & 30 \cdot 8^{\star} \\ & 750 \\ & (2 \cdot 44) \\ 174 & 204 . \\ (0 \cdot 6) & (0 \cdot 66) \\ 72.5 & 86 \cdot 5 \\ (0.25) & (0 \cdot 28) \\ & 320 \\ & (1 \cdot 04) \\ 43 \cdot 1 & 51 \cdot 8 \\ (0.15) & (0.17)\end{array}$

dynamics, doing a 50/50 mixture of pure and applied research. During the period under review some rather expensive equipment was being acquired (for example, payments for a $K D F 9$ computer of $£ 74,000$ were made in $1962 / 63$ and of $£ 148,000$ in $1963 / 64$ and the total staff increased from 1,350 to 1,425 , nearly 6 per cent in the two years). The cost of new equipment for each scientist went up from $£ 2,670$ to $£ 3,350$ in two years. In $1956 / 57$, the corresponding figure was less than $£ 1,100$. Whereas new equipment formed only 16 per cent of the annual expenditure in $1956 / 57$ that figure had risen to nearly 32 per cent by $1963 / 64$.

The annual increase of 15 per cent in expenditure on basic research by the universities and the research councils must start to drop eventually, but it could be maintained for a few more years if the rate of increase of defence expenditure on research and development were still further diminished. Moreover, for the past four years the expenditure of the Atomic Energy Authority on research and development has been almost constant at about $£ 54$ million. If the expenditure is constant (at current prices), this means that the effort is actually being reduced. It could perhaps be further reduced, because several of the tasks for which Harwell and Aldermaston were created. have been accomplished.

\begin{tabular}{|c|c|c|c|c|c|c|}
\hline & $\begin{array}{l}\text { Salaries } \\
\text { and } \\
\text { wages }\end{array}$ & $\begin{array}{c}\text { Per- } \\
\text { centage } \\
\text { of } \\
\text { increase }\end{array}$ & Equipment & $\begin{array}{l}\text { Per- } \\
\text { centage } \\
\text { of } \\
\text { increase }\end{array}$ & $\begin{array}{l}\text { Cost of new } \\
\text { equipment } \\
\text { per scientific } \\
\text { officer }\end{array}$ & $\begin{array}{l}\text { Per- } \\
\text { centage } \\
\text { of } \\
\text { increase }\end{array}$ \\
\hline $1961 / 2$ & $1,378,000$ & & 594,000 & 10 & 2,670 & \multirow{3}{*}{$\begin{array}{c}25 \cdot 5 \\
\text { in two } \\
\text { years }\end{array}$} \\
\hline $962 / 3$ & $1,446,000$ & & 651,000 & & & \\
\hline $963 / 4$ & $1,594,000$ & & 797,000 & $22^{\circ}$ & 3,350 & \\
\hline
\end{tabular}

Undoubtedly the most satisfactory way of producing more money for research and development would be to increase tho G.N.P. at a faster rate. The annual growth rate in the G.N.P. of 6 per cent is misleading, because this figure is based on current prices for each year. At constant prices, the real increase in the G.N.P. over the past five years is only about 3.4 per cent per annum. This rate has been surpassed by a considerable factor by countries like Germany, Japan and France, countries which have been devoting a much smaller fraction of their G.N.P. to research and development. Although the United States is the country which devotes the largest fraction of its G.N.P. to research, it must be remembered that this is only so because of a huge programmo in space research. If this item is eliminated, then the United States would be spending a slightly smaller fraction of its G.N.P. than Britain. Until about twenty years ago, the United States grossly neglected basic science, yet its applied science and technology were superb and surely played a great part in making its productivity far greater than the British in nearly every manufacturing industry. During the nineteenth century and the early twentieth, Britain was in the forefront technologically as well as scientifically, but we have lost our technological supremacy in many fields, not only to the United States, but to countries like Japan and Sweden. The reasons for this change are many and too complex to be analysed here, but it is generally conceded that we are not getting a sufficiently high fraction of our ablest young men to go into applied science and technology.

Because our battle to reassert ourselves technologically will take some time to win, it is worth considering whether we are making the best use of the government money at present being devoted to civil research, and whether some changes in the distribution of this money might not be made with advantage to our technological and economic future.

Table 5. SOME FIaURes From the Crvil Estimatas FOR 1966/7 (£ MILLION) Department of

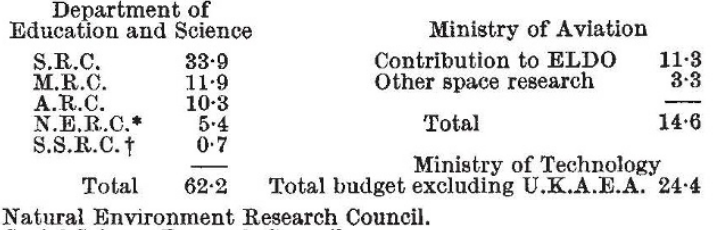

* Natural Environment Research Council.

† Social Science Research Council.

An examination of the Civil Estimates for 1966/67 reveals some figures which provide food for a good deal of thought. These are set out in Table 5. It will be seen that expenditure by the Ministry of Aviation on space research is greater than half the total budget of the Ministry of Technology. However, that is not the whole story. Through the Science Research Council an additional $£ 5.5$ million is being spent on space research, giving a total of more than $£ 20$ million, a sum almost as large as the combined expenditure of the Medical Research Council and the Agricultural Research Council. Is the expenditure of this amount of money justifiable in terms of its returns to Britain scientifically and technologically? It is often argued that "technological fall-out" justifies a large expenditure on space research, and it is certainly a field from which we should not wish to opt out completely and especially because of the potential return in the field of satellite communication. But it is possible to be active in space research with a much smaller expenditure of money.

Nuclear physics is another very expensive field of research. The estimated direct expenditure on nuclear physics by the Science Research Council during 1966/67 amounts to $£ 14.4$ million and of this $£ 1.9$ million will go as grants to university departments. The total is about 30 per cent more than the total expenditure of the Medical Research Council or the Agricultural Research Council, and more than three times the corresponding sum allocated to chemistry, metallurgy, biology, technology and the rest of physics. Is such an imbalance justifiable? Is it in the best interests of British science and technology? Is it in the best interests of British physics? Would it not be wiser to divert a larger slice of the Science Research Council's cake to solid state physics, to metallurgy, to the environmental sciences, to technology and to chemistry? The technological fall-out from nuclear physics (at least for the next few years) is surely far less than we can anticipate from all these other branches of science on each of which we spend a small fraction of what we spend on nuclear physics.

If therefore we are able to decrease our current expenditure on space research and nuclear physics, it would be quite possible to maintain an annual compound growth rate of 10-15 per cent on university research and the remainder of the research council research work for at least another three years. By this time, the new universities (the creation of which has been partly responsible for the recent steep increase in the bill for university research) might be reasonably well equipped. 